\title{
6: 7672009-7826724
}

National Cancer Institute

\section{Source}

National Cancer Institute. 6: 7672009-7826724. NCI Thesaurus. Code C41793.

Physical location of BMP6_Gene 